\title{
Creative Ceramics of Bayat Klaten: Craft Development in a Postmodern Context
}

\author{
Wiwid Safitri ${ }^{1^{*}}$ Trie Hartiti Retnowati ${ }^{2 * *}$ Bambang Prihadi ${ }^{2 * * *}$
}

\author{
${ }^{1}$ Arts Education of Graduate School, Yogyakarta State University, Yogyakarta, Indonesia \\ ${ }^{2}$ Fine Arts Education, Yogyakarta State University, Yogyakarta, Indonesia \\ *Corresponding author. Email: wiwidsafitri6@gmail.com \\ **Corresponding author. Email: trihartiti54@gmail.com \\ ${ }^{* * *}$ Corresponding author. Email: prihadi58@gmail.com
}

\begin{abstract}
The pottery craft in Indonesia faces a challenge in the postmodern era that demands them to self-adjust. This study uses qualitative approach in the case study of the Bayat Klaten's pottery industry. Data were obtained through in-depth interviews, participatory observations, and documentation. Data analysis was done using Miles and Huberman's interactive model. The findings reveal that (1) the social system at Bayat's ceramics industry was a collaborative effort among the Bayat community. This is a contributing factor in facing the challenges in postmodern era. (2) The production of the products is adjusted with the needs of the current time and creative approach. (3) There are many types of modification in the Bayat pottery products, yet they still represent old elements such as ornaments as decoration. This study is expected to develop the creative thinking skill among high school/vocational high school students through pottery making.
\end{abstract}

Keywords - pottery industry, Bayat creative pottery, postmodern

\section{INTRODUCTION}

The village of Pagerjurang, Melikan, Bayat, Klaten is a ceramic handicraft industrial area which is often referred to as Bayat ceramics. Ceramics have been around since 70,000-35,000 BC because a container of burned clay was discovered at that time [1]. The sale value of ceramics is still considered low, so the craftsmen must have a strategy. The craftsmen still preserve the traditional elements of Bayat Ceramics and adapt them to current needs. This is a strategy they run in order to survive in the postmodern era. Bayat craftsmen created postmodern art in the form of Bayat ceramics.

Postmodern art is an art that contains the elements of the past, but also follows the development and needs of the present or future. Based on the development of art craft, the emergence of art from the past is a way for craftsmen to explore the potential of art that is already owned by the craftsmen community and has become an art journey. In addition, what has already existed will again become a new art in the development of the present or postmodernism era [2]. Bayat ceramics craftsmen have done this for the sustainability of their industry. The technique of making works they used is very traditional, the ceramic forms present traditional elements, and each ceramic has different functions according to the needs of the present and has aesthetic value in its shape.

From an economic point of view, this phenomenon can be addressed as a positive response, given the diversity of businesses would open new opportunities for investment in the craft sector. This opportunity is able to provide answers to the public, not only for Indonesia but also the global community, about searching for past identities with present packaging [3]. Works in new packaging are also influenced by the openness of the craftsman's view of external parties. This openness makes Bayat ceramics flourish, including being able to create different works as the impact of postmodern culture. The external parties referred to are ceramics experts both individuals and groups from a private or government institution, as well as external parties such as buyers or connoisseurs of ceramics, as well as the influence of the development of information obtained from the mass media.

Bayat Ceramics are made in the traditional way using a rotating technique. Rotating techniques were discovered around $4000 \mathrm{BC}$ [4]. Bayat craftsmen used a traditional oblique potter's wheel in shaping their ceramics. They also use other simple tools that have been traditionally used for the manufacture of ceramics such as tools for building and smoothing the ceramics. The tools are specifically made by craftsmen with plastic materials from used items such as mineral water bottles, infusion containers, floor cleaner bottles, paint containers, etc. These materials are processed and formed with the creativity of the craftsmen to become tools for making ceramics. They recycle used goods as an alternative to reduce waste in their surrounding environment. Nuraniyah [4] revealed that Indonesian people produce around 65 million tons of waste every day. Bayat craftsmen apply the recycling strategy not only to 
reduce waste but also to prevent further environmental damage.

The making of ceramics starts from processing the clay to the final process, i.e. burning and smoking of ceramics. The beauty of ceramics can be seen from how the ceramics are made until finishing [5]. Ceramics are made from the creative ideas of craftsmen to be able to meet the needs of the postmodern era. This activity can also be carried out by young people to be able to develop Bayat ceramics in the postmodern era. This activity can be carried out in junior high schools so that the younger generation can better appreciate and develop the existing crafts. Making art is an act of discovery. If you are dealing with what you know, you may not be doing your job. When you discover something new, or surprise yourself, you are engaging in the process of discovering [6]. The young generation needs to be involved in creating something new to develop Bayat ceramics in accordance with the requirements of the postmodern era with the method of deconstruction. What is meant by deconstruction is to construct a new text or discourse with a new meaning that is different from the deconstructed text [7].

This research focused on exploring the development of Bayat ceramics from the viewpoint of the craftsmen who created ceramics to meet the needs of the postmodern era. Through case studies, this research was conducted directly in Pagerjurang Village, Melikan, Bayat, Klaten. All residents are the source of the data in this study because they are all ceramic craftsmen.

\section{RESEARCH METHOD}

This research was carried out to examine Bayat ceramics in a postmodern context. To obtain in-depth explanations, researchers used qualitative research with a case study approach. This study focused on the development of Bayat creative ceramics that could not be separated from the influence of the social system and the workings of making the artworks. Data were collected through in-depth interviews, participatory observations, and documentation. Qualitative research with a case study approach is an approach that emphasizes the exploration of a "limited system" in one case or several cases that are limited by time and events and is carried out in detail accompanied by an in-depth data mining by involving various sources of data [8]. This research was conducted in March to May 2019 in the Bayat Ceramics Industry, Pagerjurang Village, Melikan, Bayat, Klaten. Data sources were obtained from Bayat residents. In-depth interviews were conducted with several informants, including Mr. Sarjiman (a clay and sand gatherer), Mr. Eko Riyadi (a red clay gatherer), Mrs. Fajar (a mundur leaf gatherer), Mr. Rusmanto (a ceramic craftsman), and Mrs. Sudarmi (a ceramic seller). Data were analyzed using the interactive model of Miles and Huberman [9]: (a) Data Gathering, collecting data through in-depth interviews, observations, and documentation; (b) Data Reduction, reducing data to sharpen, sort, focus, discard, and organize data so that conclusions can be verified and drawn; (c) Data Presenting, organizing data and compiling information so that conclusions can be drawn to describe the situation; and (d) Verification, drawing conclusions, looking for meaning from the data obtained so that the final results can be obtained.

\section{RESULT AND DISCUSSION}

\subsection{RESULT}

The arts, including Bayat ceramics, have developed until now in the postmodern era. Bayat ceramics contains elements of the past but can still be adapted to current needs so that it remains in line with the development of the postmodern period. The manufacturing technique is still very traditional, yet the products produced are able to meet the needs of the postmodern era. Bayat craftsmen give priority to the needs of buyers while maintaining product quality and developing products to remain attractive. The ceramics produced have natural beauty and are much in demand by the public.

Bayat ceramics are much in demand by local people to the international market, because in the postmodern era the craftsmen can adjust their work to market developments. Craftsmen create ceramics that have traditional elements with present-day packaging. This has been proven by Hartanto and Gustami [10] that Bayat ceramics are able to compete in the international markets of Switzerland, Canada, Japan, and America with various shapes, patterns, and styles. These ceramics are produced with rich variations that follow today's needs. Ceramic production is the livelihood of Bayat residents. Tjitrosoepomo [11] said that the business of making ceramic crafts can increase value added.

\subsubsection{The Social System of Bayat Ceramics Industry}

The main factor influencing the development of Bayat ceramics in the postmodern era is the existence of a social system. The social system is created to assist and facilitate the development of Bayat ceramics in the postmodern era. This social system refers to an activity of producing Bayat ceramics which is carried out cooperatively. Activities undertaken jointly will facilitate the development of the industry, especially in the postmodern era in which development is not easy to do when carried out individually. The first social system is an intercitizen group. Intercitizen groups are created to facilitate the development of Bayat ceramics in mutual cooperation to meet the needs of the postmodern era. The second social system is cooperation in the distribution of work. The second social system is cooperation in the distribution of work. Task division has its own respective roles in influencing the development of Bayat ceramics in the postmodern era. The second social system is cooperation in the distribution of work. The division of labor has its respective roles to be able to influence the development of Bayat ceramics in the postmodern era. The Bayat ceramics industry can compete in the international market because of the good cooperation among its citizens, creating rich variations of ceramics for the needs of the postmodern era. 


\subsubsection{The group of clay and sand gatherers}

This group consists of 3 small groups with 3-4 members. It is their job to collect clay in the forestry located in Sayangan Village, Melikan, Wedi, Klaten. The sand is obtained from the edge of the Mundu river located in Brakal, Wedi, Klaten. Clay is sold at IDR 12,000 per guluk (roll). The price of clay per kilo is IDR 2,500. Clay and sand gatherers have collaborated with craftsmen to routinely supply clay and sand stock. Clay and sand as the main ingredients in making Bayat ceramics are processed together to create stronger ceramics.

\subsubsection{The group of red clay gatherers}

There is only one group of red clay gatherers with 4 members. They are in Paseban Village, Bayat, Klaten. This group routinely sells red clay to the craftsmen once a month. Red clay is sold at IDR 25,000 per bag. Red clay is a supporting material in making Bayat ceramics that are adapted to the needs of the postmodern era.

\subsubsection{The group of leaves gatherers}

This group has an unlimited number of members, because every citizen who has a tree, especially a mundur tree, can sell its leaves to the craftsmen. This group cooperates with the craftsmen by selling their mundur leaves every two weeks. These leaves are sold at IDR 30,000 per bag. Mundur leaves are used as an ingredient in the ceramic smoke firing process. Even so, craftsmen can also use other types of leaves as an experiment in the development of postmodern ceramics.

\subsubsection{The group of wood gatherers}

There is one wood gatherer group with 4 members. A bundle of wood is sold at IDR 17,000. The craftsmen give an advance, then the wood gatherers will find the best wood for them. The character of wood will influence the strength of the postmodern ceramics body. The wood must be dry so that the ceramics produced are strong and sturdy.

\subsubsection{The group of ceramics craftsmen and sellers}

The group of ceramics craftsmen and sellers are all residents of Pagerjurang Village who are not in charge of gathering the materials. The craftsmen group is responsible for making the ceramics, while residents who live near the main road are tasked with selling the ceramics. Craftsmen groups have two categories, namely small groups (private) and large industrial craftsmen (group or joint-owned). A small group consists of a father, a mother, and children. Private craftsmen groups can also work together with their brothers. The large industrial craftsmen group is a jointly owned industry consisting of several families and has employees with their respective duties. Thus, the work will be easier to complete.
The third social system is the routine community gathering, i.e. a gathering activity aimed to develop the Bayat ceramics industry, especially in this postmodern era. The gathering is held once a month. People in this forum can exchange knowledge about how to produce ceramics according to the needs of the postmodern era, ways of collecting materials, making equipment from used materials, etc. This routine gathering can build good relations among citizens so as to create harmony and sustainable relationships.

The harmony created through this gathering is in accordance with Prihantono's expression [12] in Javanese that "rukun nduweni teges khanan kang selaras, ayem, lan tentrem, ora ana ontran-ontran, nyawaji siji lan sijine, seneng tulung pitulung". Harmony is a way to live a harmonious and peaceful life. The collaborative activities not only make it easier to develop postmodern ceramics but also help create harmony. Three important things about cooperation are expressed by Koentjaraningrat [8] in Javanese "Wong-wong kudu sadhar yen uripe mesti nggandulake marang wong liyane, mula saka iku kudu njaga tenanan guyub rukun karo sapadhane. (2) Wongwong iku gelem lan ikhlas ngewangi sapadhane, dan (3) Wong kudu nduweni sipat conform, tegese kudu eling yen apike aja ngupayake sing paling nonjol ngluwihi saka liyane ing masarakate. The meaning of the above expression is that humans must realize that in their lives they need one another so that they must live in harmony, be sincere, help each other, and be able to adjust to their environment. Bayat residents carry out their activities in harmony in developing the postmodern ceramics.

\subsubsection{How to Make Bayat Creative Ceramics}

Bayat ceramics are made by maintaining the traditional elements of the ceramics and adjusting the needs of the present in the postmodern context. Ceramics are made by using simple tools made from used materials such as mineral water bottles, infusion containers, floor cleaner bottles, paint containers, etc. Previously, these bottles and containers had their original functions, but when they were not used anymore, they are recycled into tools for making postmodern ceramics. Bayat craftsmen use these used materials as tools in making creative ceramics. The bottles are designed and cut to be used as the ceramic body shaping tools, smoothers, and supporting tools in the process of trimming the ceramics. The use of used goods is an alternative that benefits craftsmen from an economic perspective because they can minimize the capital they spend in the production of postmodern ceramics. In addition, the quality of ceramics can also be maintained so that there is no change in quality.

The followings are the steps in making Bayat ceramics: (1) Processing the main materials (clay and sand with a ratio of $10: 1)$; (2) Smoothing the materials using a mixer machine; (3) Moisturizing the materials through ngeplok (mixing the materials by hand by rotating and pressing a clay ball); (4) Shaping the ceramics using a traditional tool, i.e. an oblique potter's wheel. Shaping is the main step in creating postmodern ceramics through a deconstruction method. 
Craftsmen adapt the elements of pre-existing works of art and transform them into contemporary works to meet the needs of the postmodern era. (5) Keeping the ceramics partially dry; (6) Refining the ceramics shapes through bubut (lathe) process using several tools prepared earlier; (7) Applying lethoh (red soil that has been deposited for one day in water) to the ceramics body using a brush; (8) Smoothing the ceramics; (9) Re-smoothign the ceramics through nglambu process (smoothing the ceramics body using a net fabric repeatedly); (10) Drying the ceramics by leaving them for at least one day; (11) Firing the ceramics in a traditional fireplace using wood and kerosene as the fuel for about 10 hours (the firing duration depends on the condition of the ceramics, weather, and the wood characteristics); and (12) Firing the ceramics through smoke-firing process using a traditional fireplace with embers which are piled with mundur leaves or other materials that have been moistened with water. This process takes approximately 2 hours, starting from 15 minutes after the first firing process is finished. The duration of this process is affected by the characteristics of the ceramics.

The following figure shows a craftsman working with an oblique potter's wheel.

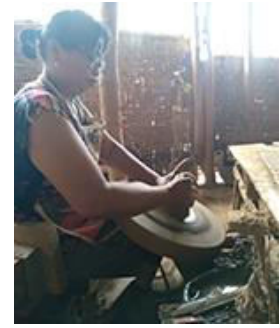

Figure 1 The shaping process of ceramics using an oblique potter's wheel

Figure 2 shows how lenthoh (red soil from Bayat that has been processed) looks like.

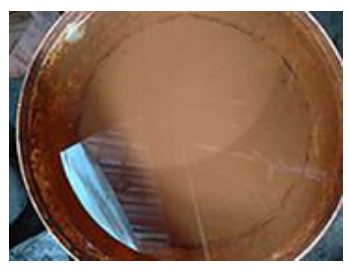

Figure 2 Lethoh

The fourth step in the process of making ceramics is the formation by using an oblique potter's wheel. This special wheel is used to produce ceramics of small size, including postmodern ceramics. The other equipment used in producing postmodern ceramics is made specifically by craftsmen by utilizing used items to create new tools. Therefore, it can be said that Bayat craftsmen have accepted postmodern culture for they utilize used objects as new equipment that is useful in making ceramics in the development of postmodern art.

The other equipment used in making Bayat ceramics includes: (a) plastics from used materials - used in shaping or smoothing the ceramics; (b) net fabrics - used in the smoothing process; (c) bottomless ceramics - used as a support in the lathe and smoothing process; (d) wire and iron bar - used in the lathe and refining process; (e) iratan (thinly cut bamboo that is usually used for making plaited mats) - used in the lathe process to refine and smooth the ceramics shape; (f) garuk - a piece of wood used to take ember from a fireplace; and (g) urak - used as a tool for scattering the embers inside the fireplace. The followings are the figures showing tools for smoothing the ceramics (Figure 3), doing the lathe process (Figure 4), and refining (Figure 5).

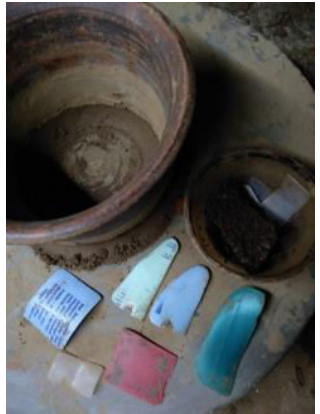

Fig. 3. Smoothing tools (bottomless ceramics, plastics from infuse tube and used bottles)

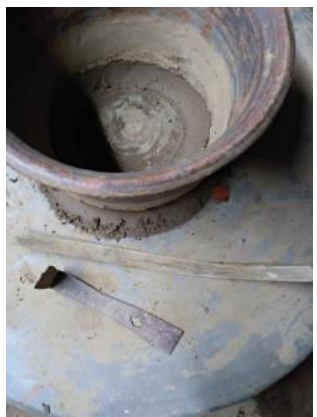

Figure 4 Tools used in the lathe process (bottomless cermaics, iratan, and iron bar)

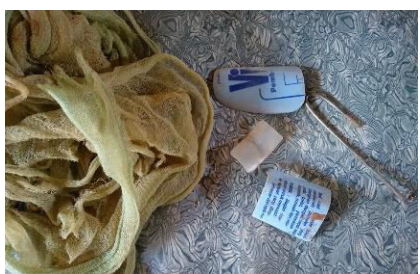

Figure 5 Tools for the refining process (net fibers, plastics from infuse tube and used bottles, and wire)

These tools are made by the craftsmen themselves to minimize their production cost as well as to reduce waste in their environment. They creatively used materials as tools for producing postmodern ceramics. This is what is called as "Artists' Creative Process". Artists are always required 
to create and develop new ideas as a form of continuity of work and as an indication of productivity [13].

\subsubsection{Bayat Creative Ceramics (in the postmodern era)}

Bayat ceramics consistently show the following characteristics: (1) blackish brown in color; (2) made of solid clay, creating strong ceramics; (3) made of a mixture of clay and sand with a ratio of 10:1; and (4) shiny with a smooth and soft quality as a result of nglambu process and the application of lethoh. Postmodern ceramics can be made by featuring one or some of the characteristics because the craftsmen can experiment on how to develop postmodern ceramics. Therefore, it is not imperative for them to present all characteristics of the traditional ceramics. They can choose which characteristics to show in a new packaging as needed in the postmodern era.

Bayat craftsmen mass-produce ceramics in different shapes according to the requests and needs of the buyers in the postmodern era. Craftsmen always develop their knowledge and abilities to be able to follow the development of the postmodern era. The influence from outside can help them to develop their knowledge and abilities. Bayat ceramics follows the development of the postmodern era but do not leave the traditional elements. The postmodern feature of these ceramics lies in the shape of the works. Here are the differences between traditional and postmodern Bayat ceramics:

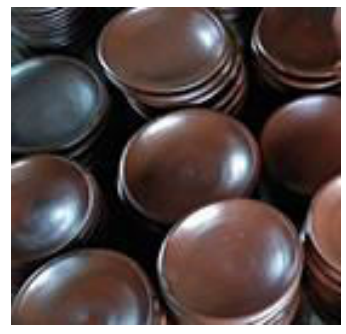

Figure 6 Traditional ceramics

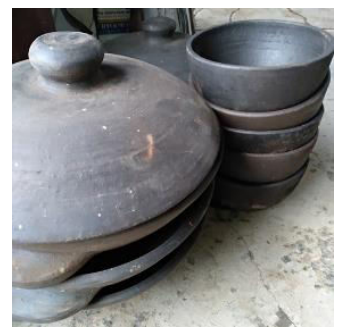

Figure 7 Modified Ceramics (Postmodern)

Figure 6 depicts some Bayat traditional ceramics. These ceramics are traditionally made both in terms of the shape and the ways they are made. They are brownish in color with smooth and shiny textures. Figure 7 shows postmodern ceramics as the modification of traditional ceramics. The shapes of these ceramics are still traditional, however the way they are made has been through some development, affecting their colors and textures. Unlike the traditional ones, these ceramics are black in color and rough in texture. These colors are resulted from the materials and techniques used in the production process. The bran used in the smoke-firing process makes the ceramics black and rough. The resulted color is no longer shiny, and the texture is not smooth. This technique is chosen to meet the aesthetic needs without leaving behind the preservation of the original shapes. This is a way to revive old products in new packaging through postmodern ceramics.

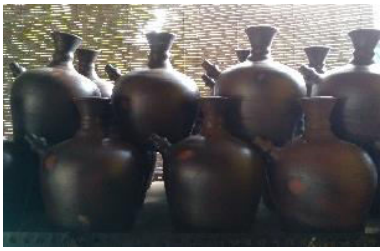

Figure 8 Traditional Ceramics (Functional Ceramics)

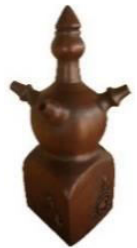

Figure 9 Postmodern Ceramics (Decorative Ceramics)

Figure 8 shows a picture of Bayat traditional ceramics in the shape of a jug (functional ceramics), while Figure 9 depicts a piece of postmodern ceramics in the form of a jug (decorative ceramics). These two ceramics are made in the same form, i.e. a jug, however their functions are different. The decorative one is made as an interior decoration to fulfill the needs of postmodern era. This new function enhances the value of Bayat ceramics, no longer as a functional thing only, but as a decoration with higher values. These postmodern ceramics are as interior decorations with aesthetic values. Technically, craftsmen preserve the old ways in changing the shapes of Bayat ceramics in the postmodern era to meet the aesthetic purpose.

The creation of postmodern ceramics is carried out by adjusting or borrowing the elements of the existing ceramics. In the fulfillment of postmodern needs, a jug as a traditional piece of traditional ceramics has special structures that fit its functions, namely the body - the main container for water; cucup - the pouring lip; and a handle. Based on the deconstruction method, this work is made in a shape of a jug, but with an addition of functional and symbolic values. The structure of this work consists of a body in the shape of a jug and a bottom in a cube shape. The bottom and the body of the ceramics are connected by a curved triangle as the transition that connect the cube to the cylinder. This firm bottom is a symbol of worship, while the body as the water container symbolize the source of life. The four pouring lips (сисир) are placed in four different positions, showing that these parts distribute energy to various directions. 


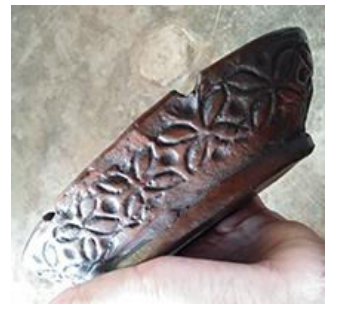

Figure 10 A modified ashtray (postmodern ceramics)

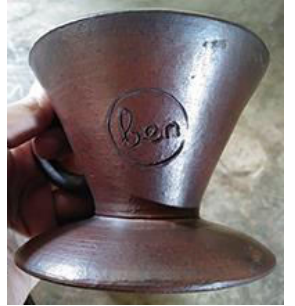

Figure 11 V60 Coffee filter (Postmodern Ceramics)

Figure 10 shows a modified ashtray made to suit the postmodern era. This ashtray is practical as inspired by the traditional element as shown in the ornament carved in its body to show the development of postmodern ceramics. Figure 11 is a piece of postmodern ceramics in the form of V60 coffee filter. The craftsmen try to meet the needs of the postmodern community who enjoy drinking coffee. This coffee filter is designed as the development of postmodern ceramics. These works are very interesting to postmodern community. Ceramics are not always identical to traditional works for they can be created in accordance with the present and postmodern needs.

\subsection{DISCUSSION}

The development of Bayat ceramics is intended to meet the needs of buyers in the postmodern era that are absolutely different from those in the past. Ceramics of the earlier era prioritize the functional aspects of the works, while those of the postmodern era add more artificial aspects in the shape of the works. The findings of this study support those of Hartanto and Gustami [10], stating that Bayat craftsmen no longer produce earthenware only, but have developed their works to decorative ceramics so that their economy can be better supported. The increasing skills and knowledge of the craftsmen gained from the external parties make it possible for them to develop these postmodern ceramics. These external parties include ceramics experts from the government, buyers as the end users, and mass media. This phenomenon does not exist in Bayat only for it happens in Kasongan, Yogyakarta as well. This is as proved by Muhajirin [14] that the development of ceramics designs in Kasongan cannot be separated from the roles of external parties in either individual, private, or state institutions such as experts, employees, scholars, etc.

The development of Bayat ceramics in this postmodern era is affected by the use of oblique potter's wheels and lethoh that are native to Bayat. Even though Bayat ceramics have changed in both shape and function in this postmodern era, the native tools and materials used in the making process are still preserved. These products are modified using tools native to Bayat, creating ceramics with shapes and functions suitable for the market demands. This finding is in similar vein with that of Yustana [2], affirming that the identity of Bayat ceramics lies in the use of lethoh and oblique potter's wheels. In addition, it is stated that time has affected the shapes and functions of the products; and the time itself is affected by the development of postmodern arts, resulting in various innovations.

The aesthetic value of Bayat ceramics functions to fulfill the decorative needs of this postmodern era. The shapes of modern ceramics are designed in accordance with their functions, while those of postmodern ceramics are enriched with aesthetic values by applying some decorations. These decorations are made by applying old elements such as various ornaments. These ceramics are not only made for practical use but also for aesthetic aspects as shown int heir shapes. Their shapes are simplified without leaving behind the traditional elements to meet the decorative needs as the development of postmodern ceramics. These products are made as inspired by the traditional elements to be then adjusted in both their shapes and functions to meet the nessd of the postmodern era. This process requires creative thinking to create new ideas so that the craftsmen are able to develop interesting postmodern artworks.

Bayat craftsmen creatively make and process the tools and the materials they use in the production process by making use of anything they can find in their surrounding environment. Sunarya [15] states that creative process might happen not only when someone is assumed to have something he wants to represent for it can be the ability of someone in a new way, or the ability to modify the existing materials by giving a certain spirit. Bayat craftsmen freely express themselves to develop their ceramics industry as a necessity in the postmodern era without leaving the traditional elements. Sunarya [15] affirms that art, including craft art, is not only subject to the pure logic of the art itself. For the development of craft arts in the present and future era, crafts are not only a product that is ready to be a spokesperson for a community but is also able to transcend the dimensions of time and place to be heard by its generation. In accordance with the reality that has happened in the Bayat ceramics industry as proved on the results of this study, Bayat craftsmen have been able to develop and adjust their works to the postmodern era.

\section{CONCLUSION}

Bayat ceramics are produced traditionally using simple tools made by the craftsmen themselves. These ceramics exist to meet the needs of the postmodern era by preserving the elements from the past. This is a strategy that they use to keep exploring the potential they have. This process has been carried out consistently for the sake of the continuity of this industry in the postmodern era. The development of postmodern ceramics must be supported by (1) the social system of Bayat creative ceramics and (2) procedures in the 
production of these ceramics that is directed towards the needs of the postmodern era.

The production of postmodern ceramics with shape modifications in accordance with the needs of the present era is expected to increase selling and at the same time to introduce Bayat ceramics to world. This development effort can also be made by external parties to help popularize Bayat ceramics in a wider scope. The implications of this study can be carried out by external parties such as senior/vocational high school students or university students majoring in fine arts or craft arts. They can develop their ideas and creativity to create postmodern ceramics. Through this way, Bayat ceramics can be further developed in the era of postmodernism.

\section{ACKNOWLEDGMENT}

The researchers would like to extend sincere gratitude to their supervisors, Head of Pagerjurang Village, Bayat community, parents, and all parties who support the smooth running of this study.

\section{REFERENCES}

[1] Gautama, N. "Keramik untuk Hobi dan Karir [Ceramics for hobbies and Careers]." Jakarta: Gramedia Pustaka Utama (2010).

[2] Sila, I. N. "Kajian Estetika Postmodern Seni Kriya di Tegallalang Gianyar Bali [Post modern aesthetic study of craft art]." Seminar Nasional Riset Inovatif (SENARI) ke-4, (2016) : 526-532.

[3] Satrio, A. A. "Kriya keramik: Wujud, Posisi, dan Perannya di Masa Kini [Ceramic crafts: their form, position and role in the present]." CORAK Jurnal Seni Kriya, (2013): 167-176. DOI: https://doi.org/10.24821/corak.v1i2.2322

[4] Karimah, Sina Ratu. "Nina Nuraniyah, Mengubah Sampah Menjadi Produk Bernilai Ekonomis [Nina Nuraniyah, converting garbage into a product of economical value]." Kompasiana Beyond Blogging, kompasiana.com, 16 May 2019. https://www.kompasiana.com/sinaratu/5cdc1a3b6d b843367e61f912/nina-nuraniyah-mengubahsampah-menjadi-produk-bernilai-ekonomis

[5] Yustana, Prima. "Bayat Ceramic (Aesthetic, Form, And Function)." Acintya Jurnal Penelitian Seni Budaya 6.1 (2014). DOI : https://doi.org/10.33153/acy.v6i1.179

[6] White, K. "101 Things to Learn in Art School". Cambridge, Mass: MIT Press (2011).

[7] Lubis, Y dan Ahyar. "Postmodernisme. Teori dan Metode [Postmodernism. Theory and Method]." Jakarta: Rajawali Press (2014).

[8] Creswell, John W. "Research design pendekatan kualitatif, kuantitatif, dan mixed [Research design qualitative, quantitative, and mixed approaches]." Yogyakarta: Pustaka Pelajar (2010).

[9] Miles, Matthew B., and A. Michael Huberman. Analisis Data Kualitatif [Qualitative Data analysis].” Tjetjep Rohendi Rohidi. Jakarta: Penerbit Universitas Indonesia (2007).

[10] Hartanto, Yusuf, and S. P. Gustami. "Seni Kerajinan Keramik Bayat Klaten dalam Dua Dasawarsa Terakhir Abad XX (Kontinuitas dan Perubahannya) [Art Crafts Ceramics Bayat Klaten in the last two decades of the XX century (continuity and its changes)]." Sosiohumanika (16/B) 16.2003 (2003).

[11] Tjitrosoepomo, Gembong. "Teknologi Tepat Guna Kerajinan Enceng Gondok [Precise technology for Water hyacinth crafts]." Universitas Wangsa Manggala (2007).

[12] Prihantono, D. Etika lan Moralitas Urip Masyarakat Jawa [Ethics and Morality Urip Community Java]." Yogyakarta: Javalitera, 2017.

[13] Endah Lestari, Dwi. "Proses Kreatif Seniman Rupa [Creative process of fine artists]." Character: Jurnal Penelitian Psikologi. 4.1 (2017). URL: https://jurnalmahasiswa.unesa.ac.id/index.php/char acter/article/view/18918

[14] Muhajirin. "Kajian Pembelajaran Informal Masyarakat Perajin Keramik Kasongan Bantul Yogyakarta [Review of Informal Learning Society of Pottery craftsmen in Bantul Yogyakarta]. ”. Imaji, 3.1 (2005) : 89-104. DOI: https://doi.org/10.21831/imaji.v3i1.6926

[15] Sunarya, I. Ketut. "Perkembangan di Tengah Perubahan Masyarakat [The Development of Crafts in the Middle of Community Change]." Imaji: Jurnal Seni dan Pendidikan Seni 4.2 (2006). URL: http://eprints.uny.ac.id/id/eprint/4860 